\title{
EXPLORING THE POTENTIAL ENERGY OF LODAGUNG MINI-HYDROPOWER PLANT IN BLITAR, WEST JAVA, INDONESIA
}

\author{
Etty Susilowati ${ }^{1}$ dan Raymond Valiant Ruritan ${ }^{2}$ \\ ${ }^{1}$ PT Jasa Tirta Energi (JTE), Indonesia \\ ${ }^{2}$ Jasa Tirta I Public Corporation, Indonesia \\ email: ettysslwt@gmail.com
}

\begin{abstract}
Renewable energy in Indonesia is not optimally developed. Most existing renewable energy power plants come from water and geothermal, but the utilized capacity is far away from significant. Lodagung mini-hydro power plant was built by The Public Corporation, Jasa Tirta I with an installed capacity of $2 \times 650 \mathrm{~kW}$ utilizing water from the Lodagung Irrigation Channel, Wlingi Dam to generate electricity in Blitar Regency, East Java. The plant has become the first to use Siphon technology in its operation. This study aims to analyse the potential power generated by Lodagung Mini-hydropower plant using primary and secondary data. The data processing was done by calculating the reliable discharge of the irrigation channel for three years since 2011 to 2013; calculating the water discharge in the siphon pipe; and calculating the estimated power generated by the plant. The findings indicate that the maximum discharge of the Lodagung irrigation channel is $13.78 \mathrm{~m} 3 / \mathrm{second}$, and the minimum discharge is $8.89 \mathrm{~m} 3 / \mathrm{second}$. The design discharge is $13.78 \mathrm{~m} 3 / \mathrm{second}$, and the maximum discharge in the siphon pipe is $3.96 \mathrm{~m} 3 / \mathrm{second} / \mathrm{pipe}$. Based on the need, the expected power generated ranges from $16.48 \mathrm{kWh} /$ day to $28.66 \mathrm{kWh} /$ day.

Keywords: renewable energy, Mini-hydropower plant, design discharge, electric power, Lodagung
\end{abstract}

\section{INTRODUCTION}

Indonesia has enormous potential electrical energy sources that can be developed as renewable energy such as air, solar, biomass, wind and geothermal energy. However, the potential sources have not been optimally used. The potential electrical energy that can be generated from renewable energy could produce $432 \mathrm{GW}$ or 7 to 8 times from the total power plants currently installed. Most existing renewable energy power plants used now come from the air and geothermal energy. About $7 \mathrm{GW}$ capacity that has been utilized commercially;
$66 \%$ is hydroelectric power while $27 \%$ is geothermal power generation (Institute for Essential Services Reform, 2019).

Rapid population and economic growth in Indonesia have forced for more electricity supply per year. The State Electricity Company, PT Perusahaan Listrik Negara, as the only national electricity provider, is still unable to fulfill the electricity supply target in all over Indonesia. The electrification ratio in rural areas only reached $98.30 \%$ in 2018 . The provision of electricity in rural areas is relatively difficult since it highly cost. It has to reach remote areas with widespread 
housing and faraway from primary power plants or substations so that adding networks cost is relatively high. In addition, the low electricity purchasing power of rural people has an impact on higher electricity subsidies (Ministry of Energy and Mineral Resources of Indonesia, 2019).

One possible solution to provide electricity in rural areas is by utilizing local energy sources through hydropower. Utilization of hydropower is also a part of the development of renewable energy, on a small scale such as Mini-hydropower plants.

One of Mini-hydropower plants is Lodagung which is located in Blitar, East Java. It was built by the Public Corporation, Jasa Tirta I with an installed capacity of $2 \times 650 \mathrm{~kW}$ utilizing water from the Lodagung Irrigation Channel, Wlingi Dam. It has been operating since 2018 (Riady, 2018). Minihydropower plants have advantages over other larger hydropower plants, including low development and operating costs due to its small scale, relatively short construction time and being able to adjust output power quickly, pollutant-free, and low risks (European Small Hydropower Association, 2010).

This study aims to analyse the potential power generated by Lodagung mini-hydro power plant. Previous studies regarding to the potential analysis of other Mini-hydropower plants in Indonesia have been carried out
(Dwiyanto et al., 2016; Anggraini et al., 2018; Pranoto et al., 2018; Dewi, 2020). The potential analysis for electric power generated by Lodagung mini-hydro power plant is still significant. It is because the shallow development of renewable energy in Indonesia and the studies conducted will contribute to the further development of mini-hydro power in various parts of Indonesia and increase the electrification ratio, especially in the rural areas.

Mini-hydropower plant is a small-scale power plant with the energy capacity less than 100 kW (Dwiyanto dkk., 2016). The working system of mini hydropower as follows. The flow of the water will produce kinetic energy. The kinetic energy of the flowing water will rotate the turbine propeller to convert the kinetic energy into mechanical energy. The turbine rotates the generator rotor which then converts the mechanical energy into electrical energy (Penche, 1998). The first hydroelectric power plant was developed in the 1880s (Nasir, 2013).

Mini-hydropower plant is a form of renewable energy sources. Minihydropower plant has some advantages over fossil or nuclear power plants. It can generate electricity at times of need, reduce power loss during transmission and supply electricity more economically with varying peak load demands whereas fossil fuel or nuclear power plants can only provide the 
baseload due to the complex operational requirements and start-up times which takes time. The construction of mini-hydro powerplants relatively take short time and it can adjust output power quickly. Minihydropower plant also do not pollute water and it has relatively low operating costs and risks.

Compared to the other sources of electrical energy such as wave, wind, and solar power plants; mini-hydropower plant has the highest efficiency (approximately $70-90 \%)$; higher capacity factor $(>50 \%)$ than solar power plants $(10 \%)$ and wind power plants $(30 \%)$; relatively stable output power (European Small Hydropower Association, 2010). Mini-hydropower plant is more efficient than small hydropower with a maximum capacity of up to $10 \mathrm{MW}$.

Mini-hydropower plant is chosen since its low cost, small in size, easy to build in remote areas and the ability to serve people who are usually unable to be served by large state-owned or private power companies (Nasir, 2013). Besides, the construction of Mini-hydropower plants does not damage the environment as caused by large-scale power plants.

Generally, there are four essential components of Mini-hydropower plants. The components are designed to flow water to the turbine. Water turbines is used to convert water energy to rotate the generator shaft; a drive system is aimed to transmit power from the turbine to the generator shaft; a generator to convert mechanical energy into electrical energy; and a control system (Harvey et al., 1993).

The working principle is to utilize potential energy from flowing water. The water is piped to the powerhouse in order to power the turbines. The rotation of the turbine shaft converts mechanical energy into electrical energy through a generator. The Mini-hydropower plant is usually built by diverting the water flow to one side of the river and then dropping it back into the same river to obtain the height of the waterfall. Todays, the potential energy changes into kinetic energy. The flowing water will hit and rotate the turbines in the powerhouse and convert kinetic energy into mechanical energy. The rotation of the turbine will drive a generator that converts mechanical energy into electrical energy (Maali, 2017).

\section{METHOD}

This study was conducted on the Lodagung irrigation channel which receives water from Wlingi Dam, Blitar, East Java. The data used are primary and secondary data. The primary data were collected in the form of the data on irrigation canals, river flow velocity, height difference from the weir to the mill, and water level on pipes. The secondary data consists of 10 daily 
discharge data for irrigation channels since 2011 to 2013 and the construction history of Wlingi Dam from the Wlingi multipurpose project report on groundwater in limestone foundation and dam safety.

The research method was carried out in the following stages: collecting primary and secondary data, calculating the reliable discharge of irrigation channels for three years, calculating the water discharge in the siphon pipe, and calculating the estimated energy produced by Lodagung Minihydropower plant.

The mainstay discharge of irrigation channels was calculated using the Weibull equation as follows (Limantara, 2010):

Where:

$$
P=\frac{m}{n+1} \times 100 \% \text { (1) }
$$

$P=$ the exceeded probability (\%)

$m=$ discharge serial number

$n$ = amount of discharge data

After calculating the mainstay discharge, the generator planned discharge $\left(Q_{d}\right)$ was determined. The planned discharge used to calculate the amount of power and energy for the three years that have been calculated previously. Installed capacity and electrical energy produced each year $(E)$ were calculated using equations (2) and (3).

$$
\begin{aligned}
& P=\eta_{\mathrm{t}} x \eta_{\mathrm{g}} x \eta_{\mathrm{tr}} x g x Q_{\mathrm{d}} x H_{n}(2) \\
& E=\xi x P x 8760(3)
\end{aligned}
$$

Where:

$$
\begin{aligned}
P= & \text { installed capacity }(\mathrm{kW}) \\
\eta_{t}= & \text { turbine efficiency; maximum } 93 \% \\
& \text { and minimum } 70 \% \\
\eta_{g}= & \text { generator efficiency }(97 \%) \\
\eta_{t r}= & \text { transformation efficiency }(98 \%) \\
Q_{d}= & \text { planned discharge }\left(\mathrm{m}^{3} / \text { second }\right) \\
H_{n}= & \text { effective head }=H_{g}-\text { losing head }(\mathrm{m}) \\
H_{g}= & \text { head gross }(\mathrm{m}) \\
E= & \text { annual energy }(\mathrm{kWh}) \\
\xi= & \text { capacity factor }
\end{aligned}
$$

Furthermore, the estimation of flow conditions in the siphon pipe was calculated using the Food and Agriculture Organization (FAO) method using equation (4).

$$
Q=C A \sqrt{2 g H}(4)
$$

Where:

$$
\begin{aligned}
& C=\text { discharge coefficient } \\
& A=\text { cross-sectional area }\left(\mathrm{m}^{2}\right) \\
& H=\text { head gross }(\mathrm{m})
\end{aligned}
$$

Discharge coefficient (C) was calculated using equation (5).

$$
\begin{aligned}
C & =\frac{1}{1+\lambda \frac{L}{d}+\sum k} \\
& =\frac{1}{1+\frac{\text { Total head loss }}{\frac{V^{2}}{2 g}}}
\end{aligned}
$$

Where:

$\lambda=$ pipe surface roughness coefficien $(0,02)$

$L=$ the total length of the channel

$d=$ siphon diameter

$\Sigma k=$ the total loss coefficient along the pipe 


\section{FINDINGS AND DISCUSSION}

Lodagung Mini-hydropower plant is a hydroelectric power plant that was built in 2016. It was planned, funded and operated independently by Jasa Tirta I Public Corporation. The construction of this project took approximately 18 months and was officially inaugurated on 20 February 2018. The aim is to produce and overcome the shortage of electricity supply by exploiting the potential of natural resources that have not been optimally utilized in various regions in Indonesia.

Lodagung Mini-hydropower plant utilizes irrigation water that flows through the Lodagung irrigation channel from Wlingi Dam, Blitar Regency, East Java. Before being utilized by Lodagung Mini-hydropower plant, the irrigation water was used to irrigate approximately 12,000 hectares of rice fields in Blitar and Tulungagung Regencies.

The irrigation water is available throughout the year with a discharge of 8 to 14 cubic meters/second. The potential for a high fall between the average water level in the reservoir and the water level in the irrigation channel is 12.5 meters. The irrigation water is utilized using intake siphon technology to absorb water and flow it through a penstock pipe. This action rotates turbines and generators to generate electricity. The turbine has a Kaplan S-type
Turbine specification. In contrast, the generator has a Synchronous generator specification produced by a European manufacturer with a total length of siphon pipe and penstock of approximately 460 $\mathrm{m}$ and a thickness of $12 \mathrm{~mm}$ (Jasa Tirta I, 2020).

The rationalization of using siphon turbines is also due to the geological and safety considerations of Wlingi Dam. It indicates that there has been water leakage in limestone soil. It has caused an elevation of the groundwater level to be parallel to the land in residential areas around the downstream reservoir and the powerhouse. This phenomenon has led to grouting cracks in the dam, and influences the design of the penstock pipe which was initially connected to the outlet of the existing irrigation channel. This channel uses the siphon principle that sucks water directly from the reservoir. There are concerns that the risk of water leakage in the lime soil will reoccur due to the vibration of heavy equipment while digging the soil in the former grouting area. Since Lodagung Mini-hydropower plant uses a siphon pipe, the pipe can be lied down on the ground level.

Widhiatmaka (2010) states that Siphon technology is an appropriate technology for Mini-hydropower plant since it can directly use existing irrigation canal water. Before the technology existed, Mini-hydropower 
plants used a soaking tub before the water was absorbed. The siphon components consist of penstock, turbine, generator, transmission system, ball valve, and draft tube.

A penstock is a channel that carries water from the irrigation channel to the turbine. The channel must be placed at a certain depth so that it can be operated both in the rainy and dry season. The tip of the penstock is given a filter so that it can filter out rubbish and dirt carried by water.

Siphon turbine is used to absorb water with a rotation of between 400 to 800 and an efficiency level of $80 \%$. Generators are useful for converting mechanical energy into electrical energy. The transmission system functions to increase the turbine rotation so that it reaches the minimum limit of generator rotation to generate electricity. Siphon turbines usually use a pulley and v-belt transmission systems. The ball valve is placed at the end of the penstock pipe, which functions to encourage and break the siphoning effect. Finally, the draft tube is a pipe that functions to reduce the speed of water leaving the turbine. The working principle of the siphon turbine is first to encourage the siphoning effect by setting the ball valve in a closed position. After that, water enters the turbine room, and the ball valve opens to suck water to turn the turbine. The turbine rotates to produce mechanical energy. The mechanical energy is used to drive a generator and generate electricity. The higher the waterfall, the greater the electrical energy generated (Widhiatmaka, 2010; Imanudin et al., 2016; Putra et al., 2018).

A hydrological analysis is performed to estimate the reliable discharge provided by the Lodagung irrigation channel. The calculation method records ten daily discharge and irrigation canal data for three years from 2011 to 2013 . The determination of the primary ten days is following the hydrological feasibility study conducted by Directorate General of Electricity and Energy Utilization, Ministry of Energy and Mineral Resources of Indonesia in 2009.

The calculation results are presented in Table 1. It is found that the maximum discharge of the Lodagung irrigation channel is $13.78 \mathrm{~m}^{3} /$ second with a probability of $2.70 \%$ and the minimum discharge is 8.89 $\mathrm{m}^{3} /$ second with a probability of $97.30 \%$. From the flow rate calculation, a planned discharge $\left(Q_{d}\right)$ of $13.78 \mathrm{~m}^{3} /$ second is determined because all available outflows are used to generate power and electrical energy due to the relatively small fluctuation of outflow of $5 \mathrm{~m}^{3} / \mathrm{second}$ (the difference between the maximum and minimum discharges).

The mainstay discharge analysis for Lodagung Mini-hydropower plant is carried 
Jurnal Penelitian Saintek, Vol. 26, Nomor 1, 2021

Table 1

The Mainstay Discharge of Lodagung Irrigation Channel from 2011 to 2013

\begin{tabular}{|c|c|c|c|c|}
\hline No & Month & Decade & Probability (\%) & Average Discharge \\
\hline 1 & January & 1 & 35,14 & 13,09 \\
\hline 2 & February & 1 & 16,22 & 13,37 \\
\hline 3 & March & 1 & 8,11 & 13,55 \\
\hline 4 & April & 1 & 21,62 & 13,33 \\
\hline 5 & May & 1 & 54,05 & 12,61 \\
\hline 6 & June & 1 & 59,46 & 11,84 \\
\hline 7 & July & 1 & 56,76 & 12,36 \\
\hline 8 & August & 1 & 62,16 & 11,57 \\
\hline 9 & September & 1 & 75,68 & 10,23 \\
\hline 10 & October & 1 & 89,19 & 9,53 \\
\hline 11 & November & 1 & 83,78 & 9,69 \\
\hline 12 & December & 1 & 40,54 & 12,76 \\
\hline 13 & January & 2 & 29,73 & 13,11 \\
\hline 14 & February & 2 & 27,03 & 13,25 \\
\hline 15 & March & 2 & 5,41 & 13,68 \\
\hline 16 & April & 2 & 24,32 & 13,29 \\
\hline 17 & May & 2 & 45,95 & 12,62 \\
\hline 18 & June & 2 & 48,65 & 12,62 \\
\hline 19 & July & 2 & 67,57 & 11,00 \\
\hline 20 & August & 2 & 70,27 & 10,66 \\
\hline 21 & September & 2 & 78,38 & 9,88 \\
\hline 22 & October & 2 & 94,59 & 9,05 \\
\hline 23 & November & 2 & 86,49 & 9,63 \\
\hline 24 & December & 2 & 37,84 & 13,02 \\
\hline 25 & January & 3 & 13,51 & 13,37 \\
\hline 26 & February & 3 & 18,92 & 13,35 \\
\hline 27 & March & 3 & 10,81 & 13,42 \\
\hline 28 & April & 3 & 32,43 & 13,1 \\
\hline 29 & May & 3 & 43,24 & 12,64 \\
\hline 30 & June & 3 & 51,35 & 12,62 \\
\hline 31 & July & 3 & 64,86 & 11,21 \\
\hline 32 & August & 3 & 81,08 & 9,73 \\
\hline 33 & September & 3 & 91,89 & 9,22 \\
\hline 34 & October & 3 & 97,30 & 8,89 \\
\hline 35 & November & 3 & 72,97 & 10,24 \\
\hline 36 & December & 3 & 2,70 & 13,78 \\
\hline
\end{tabular}


out to estimate the maximum discharge that the siphon pipe can flow. Through the calculation method recommended by the Food and Agriculture Organization (FAO), it is found that the maximum discharge of siphon pipes without regulation is $15.28 \mathrm{~m}^{3} /$ second. The pipe is regulated with two pipes with a diameter of $1.5 \mathrm{~m}$ each. The water flow in each pipe becomes $3.96 \mathrm{~m}^{3} / \mathrm{second}$. The total pipe length is $410.46 \mathrm{~m}$, and the dam peak evaluation ranges from $167 \mathrm{~m}$ (Figure 1).

The analysis of the generated electrical power was carried out to estimate the electric power that could be produced by Lodagung Mini-hydropower plant. The calculation of electric power is based on the discharge of the Lodagung irrigation channel. The assumption used is that two turbines are operating until the irrigation discharge decreases by up to $40 \%$.
Therefore, a minimum value of $2.76 \mathrm{~m}^{3} /$ second is obtained for each turbine. The value is still below the minimum discharge of the Lodagung irrigation channel, which is $8.89 \mathrm{~m}^{3} /$ second. It is estimated that the turbine can operate all year round except during repair and maintenance. The results of calculations using a 10-day discharge period based on the Reservoir Operation Pattern and Water Allocation at efficiency level of $70 \%$ to $90 \%$ suggests that the energy that can be generated ranges are from $16.48 \mathrm{kWh} /$ day to $28.66 \mathrm{kWh} /$ day (Table 2). Lodagung Mini-hydropower plant contributes to providing electricity to residents in Blitar.

\section{CONCLUSION}

The findings from this study indicate that the maximum discharge of the Lodagung irrigation channel is $13.78 \mathrm{~m}^{3 /}$

\section{Figure 1}

Design of Lodagung Siphon Pipe

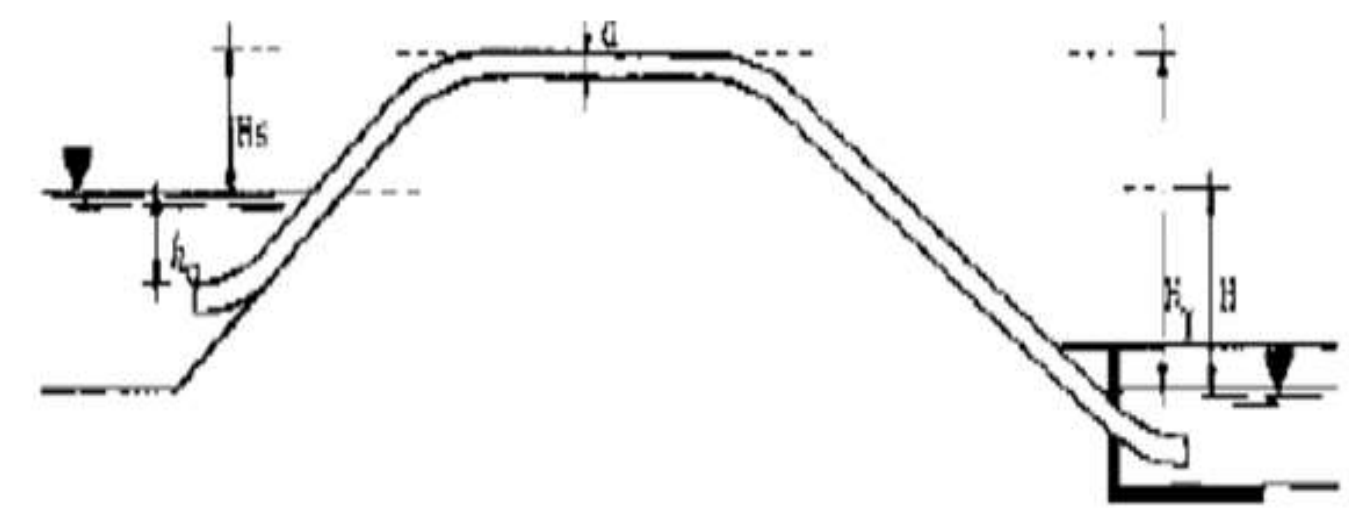


Jurnal Penelitian Saintek, Vol. 26, Nomor 1, 2021

Table 2

The Potential Energy Produced by Lodagung Mini-Hydropower Plant

\begin{tabular}{|c|c|c|c|c|c|c|c|}
\hline Month & Decade & $\begin{array}{l}\text { Irrigation } \\
\text { Channel } \\
\text { Discharge } \\
\left(\mathrm{m}^{3} / \mathrm{sec}\right)\end{array}$ & $\begin{array}{l}1^{\text {st }} \text { Turbine } \\
\text { Discharge } \\
\left(\mathrm{m}^{3} / \mathrm{sec}\right)\end{array}$ & $\begin{array}{l}2^{\text {nd }} \text { Turbine } \\
\text { Discharge } \\
\left(\mathrm{m}^{3} / \mathrm{sec}\right)\end{array}$ & $\begin{array}{c}1^{\text {st }} \text { Turbine } \\
\text { Efficiency } \\
(\%)\end{array}$ & $\begin{array}{l}2^{\text {nd }} \text { Turbine } \\
\text { Efficiency } \\
\quad(\%)\end{array}$ & $\underset{\text { day) }}{\text { Energy (kWh/ }}$ \\
\hline January & 1 & 13,09 & 6,54 & 6,54 & 90 & 90 & 27,33 \\
\hline February & 1 & 13,37 & 6,69 & 6,69 & 90 & 90 & 27,89 \\
\hline March & 1 & 13,55 & 6,77 & 6,77 & 90 & 90 & 28,22 \\
\hline April & 1 & 13,33 & 6,67 & 6,67 & 90 & 90 & 27,81 \\
\hline May & 1 & 12,61 & 6,31 & 6,31 & 90 & 90 & 26,40 \\
\hline June & 1 & 11,84 & 5,92 & 5,92 & 89 & 89 & 24,62 \\
\hline July & 1 & 12,36 & 6,18 & 6,18 & 90 & 90 & 25,82 \\
\hline August & 1 & 11,57 & 5,79 & 5,79 & 89 & 89 & 24,01 \\
\hline September & 1 & 10,23 & 5,11 & 5,11 & 86 & 86 & 20,81 \\
\hline October & 1 & 9,53 & 4,77 & 4,77 & 84 & 84 & 18,94 \\
\hline November & 1 & 9,69 & 4,84 & 4,84 & 85 & 85 & 19,44 \\
\hline December & 1 & 12,76 & 6,38 & 6,38 & 90 & 90 & 26,69 \\
\hline January & 2 & 13,11 & 6,56 & 6,56 & 90 & 90 & 27,38 \\
\hline February & 2 & 13,25 & 6,63 & 6,63 & 90 & 90 & 27,65 \\
\hline March & 2 & 13,68 & 6,84 & 6,84 & 90 & 90 & 28,47 \\
\hline April & 2 & 13,29 & 6,65 & 6,65 & 90 & 90 & 27,73 \\
\hline May & 2 & 12,62 & 6,31 & 6,31 & 90 & 90 & 26,41 \\
\hline June & 2 & 12,62 & 6,31 & 6,31 & 90 & 90 & 26,41 \\
\hline July & 2 & 11,00 & 5,50 & 5,50 & 88 & 88 & 22,68 \\
\hline August & 2 & 10,66 & 5,33 & 5,33 & 87 & 87 & 21,84 \\
\hline September & 2 & 9,88 & 4,94 & 4,94 & 86 & 86 & 19,97 \\
\hline October & 2 & 9,05 & 4,52 & 4,52 & 81 & 81 & 17,42 \\
\hline November & 2 & 9,63 & 4,82 & 4,82 & 85 & 85 & 19,26 \\
\hline December & 2 & 13,02 & 6,51 & 6,51 & 90 & 90 & 27,21 \\
\hline January & 3 & 13,37 & 6,69 & 6,69 & 90 & 90 & 27,89 \\
\hline February & 3 & 13,35 & 6,68 & 6,68 & 90 & 90 & 27,84 \\
\hline March & 3 & 13,42 & 6,71 & 6,71 & 90 & 90 & 27,98 \\
\hline April & 3 & 13,10 & 6,55 & 6,55 & 90 & 90 & 27,36 \\
\hline May & 3 & 12,64 & 6,32 & 6,32 & 90 & 90 & 26,45 \\
\hline June & 3 & 12,62 & 6,31 & 6,31 & 90 & 90 & 26,41 \\
\hline July & 3 & 11,21 & 5,60 & 5,60 & 88 & 88 & 23,17 \\
\hline August & 3 & 9,73 & 4,86 & 4,86 & 85 & 85 & 19,56 \\
\hline September & 3 & 9,22 & 4,61 & 4,61 & 82 & 82 & 17,96 \\
\hline October & 3 & 8,89 & 4,45 & 4,45 & 80 & 80 & 16,95 \\
\hline November & 3 & 10,24 & 5,12 & 5,12 & 86 & 86 & 20,83 \\
\hline December & 3 & 13,78 & 6,89 & 6,89 & 90 & 90 & 28,66 \\
\hline
\end{tabular}


second and the minimum discharge is 8.89 $\mathrm{m}^{3} / \mathrm{second}$. From the calculation of the mainstay discharge, the planned discharge is $13.78 \mathrm{~m}^{3} / \mathrm{second}$. The maximum discharge in the siphon pipe is $3.96 \mathrm{~m}^{3} / \mathrm{second} /$ pipe. The potential power generated ranges from $16.48 \mathrm{kWh} /$ day to $28.66 \mathrm{kWh} /$ day. This study has limitations since it calculates the planned discharge of irrigation channels, siphon pipes, and the potential for electric power generated.

\section{REFERENCES}

Anggraini, F. R., Juwono, P. T., \& Suhartanto, E. (2018). Studi potensi Pembangkit Listrik Tenaga Mini Hidro (PLTM) Desa Kepil, Kabupaten Wonosobo, Jawa Tengah. Jurnal Mahasiswa Jurusan Teknik Pengairan, 1(2), 14.

Dewi, R. P. (2020). Analisis potensi daya listrik aliran sungai cibuni. Power Elektronik: Jurnal Orang Elektro, 9(2), 25-29.

Dwiyanto, V., Kusumastuti, D. I., \& Tugiono, S. (2016). Analisis pembangkit listrik tenaga mikro hidro (PLTMH). Studi Kasus: Sungai Air Anak (Hulu Sungai Way Besai). Jurnal Rekayasa Sipil dan Desain, 4(3), 407-422.

European Small Hydropower Association. (2010). Energy recovery in existing infrastructures with small hydropower plants. Sixth framework programme. Mhylab, Montcherand.

Harvey, A., Hettiarachi, P., \& Iversin, A. R. (1993). Micro hydro design manual. ITDG, UK.

Imanudin, F. A., Rusdinar, A., \& Darlis, D. (2016). Rancang bangun pembangkit listrik mikrohidro (PLTMH) pada pipa saluran pembuangan air hujan vertikal. eProceedings of Engineering, 3(1).

Institute for Essential Services Reform. (2019). Laporan status energi bersih Indonesia: Potensi, kapasitas terpasang, dan rencana pembangunan pembangkit listrik energi terbarukan 2019. Retrieved from http://iesr.or.id/ wp-content/uploads/2019/07/IESR_ Infographic_Status-Energi-TerbarukanIndonesia.pdf.

Jasa Tirta I. (2020). Peresmian PLTM Lodagung Perum Jasa Tirta I. http://jasatirta1.co.id/id ID/2018/02/20/5571/ (diakses $1 \overline{1}$ September 2020).

Kementerian Energi dan Sumberdaya Mineral. (2019). Rencana umum ketenagalistrikan nasional 20192038. https://jdih.esdm.go.id/storage/ document/Kepmen-esdm-143-Thn\%20 2019\%20RUKN\%202019.pdf.

Limantara, L. M. (2010). Hidrologi praktis. Bandung: Lubuk Agung.

Maali, N. (2017). Perencanaan pembangkit listrik tenaga mikro hidro (PLTMH) Kepung Kabupaten Kediri (Doctoral dissertation). Institut Teknologi Sepuluh Nopember, Surabaya.

Nasir, B. A. (2013). Design of micro-hydroelectric power station. International Journal of Engineering and Advanced Technology, 2(5), 39-47.

Penche, C. (1998). Layman's guidebook on how to develop a small hydro site. DG XVII, European Commission.

Pranoto, B., Aini, S. N., Soekarno, H., Zukhrufiyati, A., Al Rasyid, H., \& Lestari, S. (2018). Potensi energi mikrohidro di daerah irigasi (Studi Kasus di Wilayah Sungai Serayu Opak). Jurnal Irigasi, 12(2), 77-86. 
Putra, I. G., Weking, A. I., \& Jasa, L. (2018). Analisa pengaruh tekanan air terhadap kinerja PLTMH dengan menggunakan turbin archimedes screw. Majalah Ilmiah Teknologi Elektro, 17(3), 385392.

Riady. E. (2018). PLTM Lodagung, air jadi listrik yang dinikmati warga Blitar. https://news.detik.com/berita-jawatimur/d-3876517/pltm-lodagung-airjadi-listrik-yang-dinikmati-wargablitar.

Widhiatmaka. (2010). Pengembangan PLTMH turbin siphon: Prospek dan hambatannya di Indonesia. Energi dan Ketenagalistrikan, 8(3), 82-87. 